American Journal of Applied Sciences 6 (12): 2024-2029, 2009

ISSN 1546-9239

(C) 2009 Science Publications

\title{
Accumulation of Heavy Metals in Tilapia Fish (Oreochromis niloticus) from Al-Khadoud Spring, Al-Hassa, Saudi Arabia
}

\author{
Mohammed A. Al-Kahtani \\ Department of Biology, College of Science, King Faisal University, Saudi Arabia
}

\begin{abstract}
Problem statement: Al-Khadoud Spring is one of the largest spring in Al-Hassa governorate (Saudi Arabia). Due to the extended domestic activities and urbanization as well as the continuous industrial and agricultural growth of the region, spring water quality is potentially changing. Approach: This study was conducted to measure toxic heavy metal concentrations in water and fish samples along the spring channel. Filtered spring water and tissues (liver and muscle) of captured fish were analyzed for heavy metals in an Atomic Absorption Spectrophotometer equipped with a Varian Model. Results: The concentrations of metals in water were found in the following order: $\mathrm{Fe}^{2+}>\mathrm{Zn}^{2+}>\mathrm{Cu}^{2+}>\mathrm{Pb}^{2+}>\mathrm{Mn}^{2+}>\mathrm{Cd}^{2+}$. The levels of heavy metals recorded in water in this study were generally low, when compared to WHO and USEPA recommended levels in water, except iron which was found to be higher than the recommended levels. In fish samples collected from the polluted spring, metal levels were significantly higher than the levels in water, indicating bioaccumulation. The highest levels of metals were generally reported in fish liver than muscle. Hepatic metal levels were ranked as follow: $\mathrm{Zn}^{2+}>\mathrm{Cu}^{2+}>\mathrm{Pb}^{2+}>\mathrm{Cd}^{2+}$. Conclusion: The present results showed that, the fishes, based on the higher levels of metal bioaccumulation, could be unsafe for human consumption. Consequently, very close monitoring of heavy metal loads in Al-Khadoud spring is recommended in view of the possible risks to health of consumers.
\end{abstract}

Key words: Al-Khadoud spring, Al-Hassa, water pollution, heavy metals, Oreochromis niloticus, bioaccumulation

\section{INTRODUCTION}

Chemicals derived from agricultural operations (pesticides and herbicides) and industrial effluents, such as metals, ultimately find their way into a variety of different water bodies and can produce a range of toxic effects in aquatic organisms, ranging from alterations to a single cell, up to changes in whole populations ${ }^{[1]}$. The accumulation of toxic metals to hazardous levels in aquatic biota has become a problem of increasing concern. Excessive pollution of surface waters could lead to health hazards in man, either through drinking of water and/or consumption of fish ${ }^{[2]}$. The increasing importance of fish as a source of protein and the interest in understanding the accumulation of heavy metals at the trophic levels of the food chain, extend the focus towards finfish ${ }^{[3,4]}$. Pollution enters fish through five main routes: Via food or non-food particles, gills, oral consumption of water and the skin. On absorption, the pollutant is carried in blood stream to either a storage point or to the liver for transformation and/or storage. Pollutants transformed in the liver may be stored there or excreted in bile or transported to other excretory organs such as gills or kidneys for elimination or stored in fat, which is an extra hepatic tissue ${ }^{[5,6]}$. The concentration of any pollutant in any given tissue therefore depends on its rate of absorption and the dynamic processes associated with its elimination by the fish.

Stocks of both freshwater and marine fish within Saudi Arabia are increasingly threatened by aquatic pollution, but no data are available on the extent pollution impacts. Our previous study at El-Khadoud spring showed that its water had an obvious increase in electrical conductivity, Chemical Oxygen Demand (COD), total alkalinity, nitrates, phosphorus, chloride and potassium ${ }^{[7]}$. These features indicated pollution with organic wastes, increased salinity and deteriorated oxygenated state. In the present work, heavy metal accumulation levels in water samples and fish tissues (liver and muscle) of Oreochromis niloticus from that contaminated water body at Al-Hassa were determined to assess the public health risks associated with consuming fish harvested from this area.

\section{MATERIALS AND METHODS}

Study area: Al-Khadoud Spring is one of the largest spring in Al-Hassa governorate. Al-Hassa is situated at $25^{\circ} 05^{\prime}$ and $25^{\circ} 40^{\prime}$ northern latitude and $49^{\circ} 55^{\prime}$ eastern 
longitude; located in eastern region of Saudi Arabia, $140 \mathrm{~km}$ south-west of Dammam city (Fig. 1). Al-Hassa has a dry, tropical climate, with a five-month summer and a relatively cold winter. This oasis region is wellknown for its date farming. To increase water for irrigation, the water pumped into the spring canals so to increase the amount of water used for local irrigation. Over the years, the spring and its connected canals have become a place of fish and other aquatic organisms' growth. In fact, this water body has attracted the attention of local people for fishery. Due to the extended domestic activities and urbanization as well as the continuous industrial and agricultural growth of the region, spring water quality is potentially changing. Some of untreated domestic and agricultural sewage may elapse into spring water. Such contamination must be an important issue regarding the health of the aquatic ecosystem and its animals and in turn, to human's health.

Sampling strategy: Tilapia fish (Oreochromis niloticus) with length of 12-19 $\mathrm{cm}$ and weight of 40-60 g were collected by bottom trap net from Al-Khadoud spring channel. Sampling was carried out monthly between January and December 2007. Fish samples were taken from three stations. Station I is the main water basin of Al-Khadoud spring. It is located between $25^{\circ} \mathrm{N}$ and $49^{\circ} \mathrm{E}$. The water at this point is relatively unpolluted. Stations II and III are located on the irrigational channel of the spring (5 and $10 \mathrm{~km}$ north of Al-Khadoud spring, respectively) (Fig. 2). Station III is a point source of effluents (sewage and runoff from agricultural fields). Fishing is intense at this station. On each occasion, fish samples were collected in three replicate spots at each station. Fish samples were placed in plastic bags and were stored frozen at $-10^{\circ} \mathrm{C}$ after cleaning with distilled water to remove adhering dirt. Spontaneously with fish capture, sampling of water was carried out from the particular catch area. Water samples were taken at $20 \mathrm{~cm}$ depth in $250 \mathrm{~mL}$ plastic bottles cleaned with detergent and soaked overnight in 5\% nitric acid. All samples were stored frozen at $-10^{\circ} \mathrm{C}$.

Sample treatment: All frozen samples were allowed to thaw at room temperature. Water samples were mixed vigorously and aspirated in an Atomic Absorption Spectrophotometer for trace metal determination ${ }^{[8]}$. The fish samples after defrosting were dissected; liver and muscle were taken with the help of a stainless steal stiletto. After dissection, all the tissue samples were separately oven-dried to constant weight at $105 \pm 20^{\circ} \mathrm{C}$ and were each ground to powder. The powdered samples were digested according to Sreedevi et al. ${ }^{[9]}$.

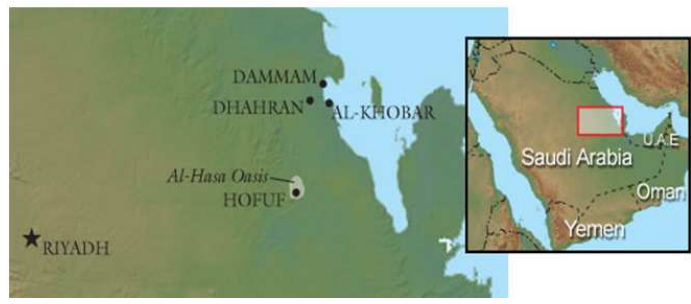

Fig. 1: Map of the study area

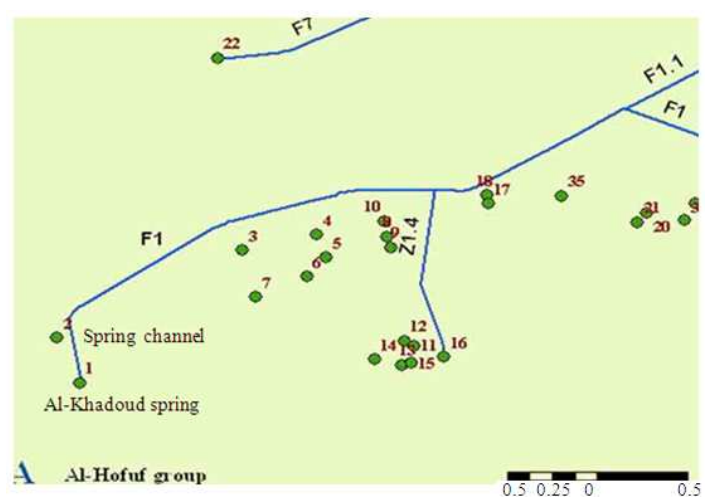

Fig. 2: Map of Al-Khadoud spring and other water springs in Al-Hassa Oasis

One gram of each sample was digested using 1.5.1 mixture of $70 \%$ perchloric acid, concentrated nitric acid and concentrated sulphuric acid at $80 \pm 5^{\circ} \mathrm{C}$ in a fume chamber, until colorless liquid was obtained. Each digested sample was made up to $20 \mathrm{~mL}$ with de-ionized water and analyzed for heavy metals in an Atomic Absorption Spectrophotometer (AA-6800F, Shimadzu, Japan) equipped with a Varian Model (GFA-EX7, Shimadzu, Japan $)^{[8]}$. Values of heavy metals were recorded in $\mu \mathrm{g} \mathrm{g}^{-1}$ dry weight.

Statistical analysis: One-way ANOVA was used for detection of differences in heavy metal concentrations between locations. Individual differences were detected by appropriate ad hoc tests (LSD). $\mathrm{p}<0.05$ was considered statistically significant.

\section{RESULTS AND DISCUSSION}

The process whereby an organism concentrates metals in its body from the surrounding medium or food, either by absorption or ingestion is known as bioaccumulation ${ }^{[10]}$. According to Heath ${ }^{[5]}$, fish can regulate metal concentration to a certain limit after which bioaccumulation occurs. The concentration of metals in an organism's body vary from organ to organ and is the product of an equilibrium between the concentration of the metal in an organism's environment and its rate of ingestion and excretion ${ }^{[11-13]}$. 
Am. J. Applied Sci., 6 (12): 2024-2029, 2009

Table 1: Mean values of some tested heavy metals concentrations $\left(\mathrm{mg} \mathrm{L}^{-1}\right)$ in water of Al-Khadoud spring channel compared to the international permissible limits

\begin{tabular}{lllllll}
\hline Metal & $\mathrm{Cd}^{2+}$ & $\mathrm{Cu}^{2+}$ & $\mathrm{Fe}^{2+}$ & $\mathrm{Mn}^{2+}$ & $\mathrm{Pb}^{2+}$ & $\mathrm{ND}$ \\
\hline Station I & $0.004^{\mathrm{a}}$ & $0.005^{\mathrm{a}}$ & $0.980^{\mathrm{a}}$ & $\mathrm{ND}$ & $\mathrm{ND}$ & $0.030^{\mathrm{a}}$ \\
Station II & $0.004^{\mathrm{a}}$ & $0.005^{\mathrm{a}}$ & $0.982^{\mathrm{a}}$ & $\mathrm{ND}$ & $0.030^{\mathrm{a}}$ \\
Station III & $0.004^{\mathrm{a}}$ & $0.022^{\mathrm{b}}$ & $2.210^{\mathrm{b}}$ & 0.017 & 0.021 & $0.031^{\mathrm{a}}$ \\
WHO $^{[15]}$ & 0.05 & 1.000 & 1.000 & 0.010 & 0.050 & 5.000 \\
USEPA $^{[16]}$ & 0.01 & 1.000 & 1.000 & 0.050 & 0.050 & 1.000 \\
\hline
\end{tabular}

Means $(\mathrm{n}=10)$; ND: Non Detectable; Values within columns with no common superscripts are significantly different $(\mathrm{p}<0.05)$

Table 2: Seasonal copper concentrations $\left(\mathrm{Cu}^{2+}\right)\left(\mu \mathrm{g} \mathrm{g}^{-1}\right.$ dry weight $)$ in organs of Tilapia fish, Oreochromis niloticus, collected from Al-Khadoud spring channel at station III during the investigation period

\begin{tabular}{lll}
\hline Seasons & Liver & Muscles \\
\hline Autumn & $216.23 \pm 28.50^{\mathrm{a}}$ & $1.73 \pm 0.16^{\mathrm{a}}$ \\
Winter & $146.02 \pm 7.05^{\mathrm{b}}$ & $2.53 \pm 0.20^{\mathrm{a}}$ \\
Spring & $644.96 \pm 58.90^{\mathrm{c}}$ & $2.52 \pm 0.17^{\mathrm{a}}$ \\
Summer & $445.16 \pm 18.33^{\mathrm{d}}$ & $3.06 \pm 0.20^{\mathrm{a}}$ \\
Total average & 363.09 & 2.46 \\
\hline
\end{tabular}

Means \pm SE $(\mathrm{n}=10)$; Values within columns with no common superscripts are significantly different $(\mathrm{p}<0.05)$

Table 3: Seasonal cadmium concentrations $\left(\mathrm{Cd}^{2+}\right)\left(\mu \mathrm{g} \mathrm{g}^{-1}\right.$ dry weight) in organs of Tilapia fish, Oreochromis niloticus, collected from Al-Khadoud spring channel at station III during the investigation period

\begin{tabular}{lll}
\hline Seasons & Liver & Muscles \\
\hline Autumn & $17.65 \pm 1.76^{\mathrm{a}}$ & $0.39 \pm 0.04^{\mathrm{a}}$ \\
Winter & $12.73 \pm 0.39^{\mathrm{a}}$ & $0.19 \pm 0.03^{\mathrm{a}}$ \\
Spring & $3.13 \pm 0.29^{\mathrm{b}}$ & $0.25 \pm 0.02^{\mathrm{a}}$ \\
Summer & $2.66 \pm 0.14^{\mathrm{b}}$ & $0.31 \pm 0.03^{\mathrm{a}}$ \\
Total average & 9.04 & 0.28 \\
\hline
\end{tabular}

Means \pm SE $(n=10)$; Values within columns with no common superscripts are significantly different $(\mathrm{p}<0.05)$

Table 4: Seasonal lead concentrations $\left(\mathrm{Pd}^{2+}\right)\left(\mu \mathrm{g} \mathrm{g}^{-1}\right.$ dry weight) in organs of Tilapia fish, Oreochromis niloticus, collected from Al-Khadoud spring channel at station III during the investigation period

\begin{tabular}{lll}
\hline Seasons & Liver & Muscles \\
\hline Autumn & $133.06 \pm 11.95^{\mathrm{a}}$ & $1.65 \pm 0.07^{\mathrm{a}}$ \\
Winter & $119.03 \pm 1.47^{\mathrm{a}}$ & $1.51 \pm 0.07^{\mathrm{a}}$ \\
Spring & $113.12 \pm 1.25^{\mathrm{a}}$ & $1.38 \pm 0.03^{\mathrm{a}}$ \\
Summer & $47.86 \pm 0.81^{\mathrm{b}}$ & $1.41 \pm 0.04^{\mathrm{a}}$ \\
Total average & 103.26 & 1.49 \\
\hline
\end{tabular}

Means \pm SE $(\mathrm{n}=10)$; Values within columns with no common superscripts are significantly different $(\mathrm{p}<0.05)$

Table 5: Seasonal zinc concentrations $\left(\mathrm{Zn}^{2+}\right)\left(\mu \mathrm{g} \mathrm{g}^{-1}\right.$ dry weight) in organs of Tilapia fish, Oreochromis niloticus, collected from Al-Khadoud spring channel at station III during the investigation period

\begin{tabular}{lcl}
\hline Seasons & Liver & Muscles \\
\hline Autumn & $534.57 \pm 5.80^{\mathrm{a}}$ & $22.26 \pm 1.62^{\mathrm{a}}$ \\
Winter & $1050.27 \pm 7.70^{\mathrm{b}}$ & $20.52 \pm 1.21^{\mathrm{a}}$ \\
Spring & $882.70 \pm 5.70^{\mathrm{c}}$ & $10.72 \pm 1.45^{\mathrm{a}}$ \\
Summer & $917.93 \pm 5.93^{\mathrm{d}}$ & $33.14 \pm 0.15^{\mathrm{a}}$ \\
Total average & 846.37 & 21.66 \\
\hline
\end{tabular}

Means \pm SE $(\mathrm{n}=10)$; Values within columns with no common superscripts are significantly different $(\mathrm{p}<0.05)$
Bioaccumulation of metal within an organism results from interactions between physiological factors (growth, weight loss, absorption and accumulation), chemical factors (metal concentration, speciation and bioavailability) and environmental factors (temperature and food concentration $)^{[14]}$.

The seasonally mean concentrations of the heavy metals $\left(\mathrm{Cd}^{2+}, \mathrm{Cu}^{2+}, \mathrm{Fe}^{2+}, \mathrm{Mn}^{2+} \mathrm{Pb}^{2+}\right.$ and $\left.\mathrm{Zn}^{2+}\right)$ in $\mathrm{Al}-$ Khadoud Spring water compared with $\mathrm{WHO}^{[15]}$ and USEPA $^{[16]}$ allowable limits are presented in Table 1. The data shows that there is no difference between $\mathrm{Cd}^{2+}$ and $\mathrm{Zn}^{2+}$ concentrations on all stations. The seasonal concentrations of $\mathrm{Cu}^{2+}$ in water ranged between 0.005 at station I to $0.022 \mathrm{mg} \mathrm{L}^{-1}$ at station III. However, $\mathrm{Fe}^{2+}$ concentration on station III was found to be much higher $\left(2.210 \mathrm{mg} \mathrm{L}^{-1}\right)$ than other two stations. On the other hand, $\mathrm{Mn}^{2+}$ and $\mathrm{Pb}^{2+}$ values ranged from Non Detectable (ND) level at station I and II (0.017 and $0.021 \mathrm{mg} \mathrm{L}^{-1}$, respectively) to $0.021 \mathrm{mg} \mathrm{L}^{-1}$ at station III. The most pronounced feature is the highest concentration of $\mathrm{Fe}^{2+}$ in Al-Khadoud $\left(2.210 \mathrm{mg} \mathrm{L}^{-1}\right)$ in comparison to other metals. Analysis Of Variance (ANOVA) of metals levels, showed no significant differences ( $p>0.05$ ) among the stations, except for $\mathrm{Cu}^{2+}$ and $\mathrm{Fe}^{2+}$. The concentrations of metals in water were found in the following order:

$$
\mathrm{Fe}^{2+}>\mathrm{Zn}^{2+}>\mathrm{Cu}^{2+}>\mathrm{Pb}^{2+}>\mathrm{Mn}^{2+}>\mathrm{Cd}^{2+}
$$

The levels of heavy metals recorded in water in this study were generally low, when compared to $\mathrm{WHO}^{[15]}$ and USEPA $^{[16]}$ recommended levels in water, except iron which was found to be higher than the recommended levels. The high level of $\mathrm{Cu}^{2+}, \mathrm{Fe}^{2+}, \mathrm{Mn}^{2+}$ and $\mathrm{Pb}^{2+}$ at station III could be attributed to discharge of either treated sewage water or re-use drainage water on the Al-Khadoud irrigation canal ${ }^{[7]}$.

In fish collected from the polluted station III, metal levels were significantly higher than the levels in water, indicating bioaccumulation. In the present study, the highest levels of metals were generally reported in fish liver than muscles (Table 3-5). Hepatic metal levels were ranked as follow: $\mathrm{Zn}^{2+}>\mathrm{Cu}^{2+}>\mathrm{Pb}^{2+}>\mathrm{Cd}^{2+}$. The fish liver plays a primary role in the metabolism and 
excretion of xenobiotic compounds with morphological alterations occurring in some toxic conditions ${ }^{[17]}$. Metals can either increase or decrease hepatic enzyme activities and can lead to histopathological hepatic changes, depending on the metal type and concentration, fish species, length of exposure and other factors ${ }^{[18]}$. Regarding the fish muscle, $\mathrm{Zn}^{2+}$ was a little bit higher whereas $\mathrm{Cu}^{2+}, \mathrm{Pb}^{2+}$ and $\mathrm{Cd}^{2+}$ were characteristically low in the same site and $\mathrm{Cd}^{2+}$ was significantly the least. These findings suggest that heavy metals (like $\mathrm{Pb}$ and $\mathrm{Cd}$ ), which have high affinity for thiol groups, turn proteins and peptides susceptible to structural modifications in sub-cellular compartments and tissues as in skeletal muscle. Some authors have already observed that cadmium alters calcium homeostasis ${ }^{[19]}$. Inhibitory effects of cadmium, lead and mercury on $\mathrm{Ca}^{+2}$-ATPase activity from sarcoplasmic reticulum in rabbits were described ${ }^{[20]}$. Morphological alterations in cultured skeletal muscle cell line as reflection of cadmium contamination altering the cell adhesion and the cellular antioxidant defense mechanisms were also described ${ }^{[21]}$.

Although the crucial role of zinc and copper in several enzymatic processes, they are tentatively classified as highly toxic metals by Hellawell ${ }^{[22]}$ and are bioaccumulated in aquatic organisms. Carino and Cruz $^{[23]}$ suggested that higher concentrations of zinc impair reproductive success and survival potential of Tilapia nilotica in zinc-contaminated ecosystems. This heavy metal can exert adverse toxicological effects, when present in high concentrations in water ${ }^{[24]}$. In fact, it is potentially toxic when the internal available concentration exceeds the capacity of physiological detoxification processes. On the other hand, organs of aquatic animals may accumulate copper when exposed to toxic concentrations ${ }^{[25]}$, which can lead to redox reactions generating free radicals and, therefore, may cause biochemical and morphological alterations ${ }^{[26,27]}$. In addition, $\mathrm{Pb}$ residues could result in haematological, gastrointestinal and neurological dysfunction in animals. Severe or prolonged exposure to $\mathrm{Pb}$ may also cause chronic nephropathy, hypertension and reproductive impairment. $\mathrm{Pb}$ inhibits enzymes, alters cellular calcium metabolism and slows nerve conduction $^{[28]}$. In parallel, cadmium is a widespread environmental pollutant that is highly toxic and is considered to have no biological function ${ }^{[29]}$. It causes severe membrane integrity damage with a consequent loss of membrane-bound enzyme activity which can result in cell death ${ }^{[30]}$. This and other nonessential metals have been reported to cause anemia both in mammals ${ }^{[31]}$ and in fish ${ }^{[32]}$.

\section{CONCLUSION}

The present results showed that, the fishes, based on the higher levels of metal bioaccumulation, could be unsafe for human consumption. The finding is worrisome in view of the health implications for the population that depend on the spring for their water and fish requirements. Consequently, very close monitoring of heavy metal loads in Al-Khadoud spring is recommended in view of the possible risks to health of consumers.

\section{ACKNOWLEDGEMENT}

I thank the Scientific Research Deanship of King Faisal University for financial support (Grant No: 8082). I also appreciate the help of technicians in Biology and Chemistry Departments.

\section{REFERENCES}

1. Bernet, D., H. Schmidt, W. Meier, P. BurkhardtHol and T. Wahli, 1999. Histopathology in fish: Proposal for a protocol to assess aquatic pollution. J. Fish Dis., 22: 25-34. DOI: 10.1046/j.13652761.1999.00134.x

2. Mathis, B.J. and T.F. Cummings, 1973. Selected metals in sediments, water and biota of the Illinois River. J. Water Poll. Cont. Trop., 45: 1573-1583. PMID: 4720140

3. Deb, S.C. and S.C. Santra, 1997. Bioaccumulation of heavy metals in fishes. An in-vivo experimental study of sewage-fed ecosystem. Environment, 17: 27-32. DOI: 10.1023/A:1018579312038

4. Obasohan, E.E., 2007. Heavy metals concentrations in the offal, gill, muscle and liver of a freshwater mudfish (Parachanna obscura) from Ogba River, Benin city, Nigeria. Afr. J. Biotechnol., $\quad 6$ : 2620-2627. http://www.bioline.org.br/pdf?jb07468

5. Heath, A.G., 1991. Water Pollution and Fish Physiology. Lewis Publishers, Boca Raton, Florida, USA., ISBN: 0873716329, pp: 359.

6. Nussev, G., J.H.J. Van Vuren and H.H. Du Preez, 2000. Bioaccumulation of chromium, manganese, nickel and lead in the tissues of the moggel, labeo umbratus (Cyprinidae), from Witbank Dam, Mpumalanga. Water SA, 26: 269-284. http://cat.inist.fr/?aModele $=$ afficheN\&cpsidt $=973444$

7. Fathi, A.A. and M. Al-Kahtani, 2009. Water quality and planktonic communities in Al-khadoud spring, Al-Hassa, Saudi Arabia. Am. J. Environ. Sci., $\quad 5$ : 434-443. http://www.akademik.unsri.ac.id/download/journal /files/scipub/ajes53434-443.pdf 
8. American Public Health Association, (APHA), 1989. Standard Methods for Examination of Water and Waste Water. 15th Edn., American Public Health Association, Washington DC., ISBN: 087553161X, pp: 1134.

9. Sreedevi, P.A., B. Suresh, B. Siraramkrishna, B. Prebhavarhi and K. Radhakrishriaiah, 1992. Bioaccummulation of nickel in organs of the freshwater fish, Cyprino carpio and the freshwater mussel. Lamelhdens marginalis under lethal and sublethal nickel stress. Chemosphere, 24: 29-36. DOI: 10.1016/0045-6535(92)90564-8

10. Forstner, U. and G.T.W. Wittmann, 1981. Metal Pollution on the Aquatic Environment. SpringVerlag, Berlin, Heidelberg, New York, ISBN: 0387093079, pp: 486.

11. Oronsaye, J.A.O., 1987. Uptake and loss of absorbed cadmium by stickleback (Gasterosteus aculeatus (L). Ecotoxicol. Environ. Safe., 14: 88-96. DOI: 10.1016/01476513(87)90087-X

12. Gerhardt, A., 1992. Review of impact of heavy metals on stream invertebrate with special emphasis on acid conditions. Water Air Soil Pollut., 66: 289-314. DOI: 10.1007/BF00479852

13. Adeyeye, E.I., N.J. Akinyugha, M.E. Fesobi and V.O. Tenabe, 1996. Determination of some metals in Clarias gariepinus (Cuvier and Valenciennes), Cyprino carpio (L) and Oreochromis niloticus (L.) fishes in a polyculture freshwater pond and their environments. Aquaculture, 147: 205-214. DOI: 10.1016/S0044-8486(96)01376-2

14. Casas, S. and C. Bacher, 2006. Modeling trace metal $(\mathrm{Hg}$ and $\mathrm{Pb})$ bioaccumulation in the mediterranean mussel, Mytilus galloprovincialis, applied to environmental monitoring. J. Sea Res., 56: 168-181. DOI: 10.1016/j.seares.2006.03.006

15. World Health Organization (WHO), 1985. Guidelines for Drinking Water Quality (Recommendations). WHO, Geneva, ISBN: 92-4154696-4, pp: 130.

16. United States Environmental Protection Agency (USEPA), 1986. Quality Criteria for Water. EPA440/5-86-001, Office of Water Regulations and Standards, Washington DC., USA.

17. Rocha, E. and R.A.F. Monteiro, 1999. Histology and Cytology of Fish Liver: A Review. In: Ichthyology: Recent Research Advances, Saksena D.N. (Ed.). Science Publishers, Enfield, New Hampshire. ISBN: 1-57808-053-3, pp: 321-344.
18. Paris-Palacios, S., S. Biagianti-Risbourg and G. Vernet, 2000. Biochemical and (ultra)structural hepatic perturbation of Brachydanio rerio (Teleostei, Cyprinidae) exposed to two sublethal concentrations of copper sulphate. Aquat. Toxicol., 50: 109-124. DOI: $10.1016 /$ S0166445X(99)00090-9

19. Pratap, H.B. and S.E. Wendelaar Bonga, 2007. Calcium homeostasis in low and high calcium water acclimatized Oreochromis mossambicus exposed to ambient and dietary cadmium. J. Environ. Biol., 28: 385-393. PMID: 17929754

20. Hechtenberg, S. and D. Beyersmann, 1991. Inhibition of sarcoplasmic reticulum $\mathrm{Ca}^{2+}$-ATPase activity by cadmium, lead and mercury. Enzyme, 45: 109-115. PMID: 1840035

21. Yano, C.L. and M.C.C.G. Marcondes, 2005. Cadmium chloride-induced oxidative stress in skeletal muscle cells in vitro. Free Rad. Biol. Med., 39: 1378-1384. DOI: 10.1016/j.freeradbiomed.2005.07.001

22. Hellawell, J.M. Ed., 1986. Biological Indicators of Freshwater Pollution and Environmental Management. Elsevier Applied Science Publishers Ltd., London and New York, ISBN: 101851660011, pp: 546.

23. Carino, V.S. and N.C. Cruz, 1990. Effects of low levels of zinc on the ovarian development of Tilapia nilotica Linnaeus. Sci. Diliman, 3: 34-45. http://journals.upd.edu.ph/index.php/sciencedilima n/article/view/287/272

24. Pelgrom, S., L. Lamers, R. Lock, P. Balm and S.W. Bonga, 1995. Integrated physiological response of tilapia, Orechromis mossambicus, to sublethal copper exposure. Aquat. Toxicol., 32: 303-320. DOI: 10.1016/0166-445X(95)00004-N

25. Mazon, A.F., C.C.C. Cerqueira and M.N. Fernandes, 2002. Gill cellular changes induced by copper exposure in the South American tropical freshwater fish Prochilodus scrofa. Environ. Res., 88: 52-63. DOI: 10.1006/enrs.2001.4315

26. Varanka, Z., I. Rojik, I. Varanka, J. Nemcsk and M. Abraham, 2001. Biochemical and morphological changes in carp (Cyprinus carpio L.) liver following exposure to copper sulfate and tannic acid. Comput. Biochem. Physiol. C., 128: 467-478. PMID: 11255117

27. Monteiro, S.M., J.M. Mancera, A. FontasnhasFernandes and M. Sousa, 2005. Copper induced alterations of biochemical parameters in the gill and plasma of Oreochromis niloticus. Comput. Biochem. Physiol. C., 141: 375-383. DOI: 10.1016/j.cbpc.2005.08.002 
28. Lockitch, G., 1993. Perspectives on lead toxicity. Clin. Biochem., 26: 371-381. PMID: 8299207

29. Hallenbeck, W.H., 1984. Human health effects of exposure to cadmium. Cell. Mol. Life Sci., 40: 136-142. DOI: 10.1007/BF01963576

30. Younes, M. and C.P. Siegers, 1984. Interrelation between lipid peroxidation and other hepatotoxic events. Biochem. Pharmacol., 33: 2001-2003. DOI: 10.1016/0006-2952(84)90564-1

31. Kostic, M.M., B. Ognjanovic, S. Dimitrijevic, R.V. Zikic and A. Stajn et al., 1993. Cadmium-induced changes of antioxidant and metabolic status in red cells of rats: In vivo effects. Eur. J. Haematol., 51: $\quad 86-92$. DOI: $\quad 10.1111 / \mathrm{j} .1600-$ 0609.1993.tb01598.x
32. Gwozdzinski, K., H. Roche and G. Peres, 1992. The comparison of the effects of heavy metal ions on the antioxidant enzyme activities in human and fish Dicentrarchus labrax erythrocytes. Comput. Biochem. Physiol. C., 102: 57-60. PMID: 1358529 